\title{
Microscopic characterization and formation mechanisms of deep- water sandy-debris-flow and turbidity-current sandstones in a lacustrine basin: a case study in the Yanchang Formation of the Ordos Basin, China
}

\author{
Jian-Bo Liao ${ }^{1,2,3} \cdot$ Ai-Hua Xi ${ }^{1} \cdot$ Zhi-Yong $\mathrm{Li}^{2,3} \cdot$ Hua-Qing $\mathrm{Liu}^{2} \cdot \mathrm{Xiang}^{\mathrm{B}} \mathrm{Bo} \mathrm{Li}^{2} \cdot$ Rong Wanyan ${ }^{2}$
}

Received: 11 January 2017 / Published online: 19 January 2018

(C) The Author(s) 2018. This article is an open access publication

\begin{abstract}
Deep-water deposition is a current issue in sedimentological research. Sandy-debris-flow sandstones and turbidity-current sandstones are the main types of sandstone that are the focus of considerable disputes in this research. Previous studies mainly focused on description of the macroscopic sedimentary structure and theoretical derivation of the formation mechanisms. The microscopic petrological characteristics, reservoir properties, and formation mechanisms of deep-water sandy-debris-flow and turbidity-current sandstones have been studied in the Yanchang Formation of the Ordos Basin, China, by means of field outcrop surveys, thin-section identification, geochemical element analysis, and porosity and permeability measurements under overburden pressure. The content of detrital grains in the sandy-debris-flow sandstones is high, whereas the contents of mica sheets and matrix are low. The fine-grained matrix is distributed unevenly within the pores. A considerable number of residual intergranular pores are preserved in the middle of single sand bodies, resulting in relatively better reservoir properties. The total number of detrital grains in the turbidite sandstone is low, while it contains abundant mica sheets and matrix. The mica sheets and fine-grained matrix are distributed evenly within the pores, resulting in serious damage to pores and poor reservoir properties. The sandy-debris-flow sandstones in the center of the lake basin form a high-quality reservoir; thus, this area is suitable for oil and gas exploration.
\end{abstract}

Keywords Sandy debris flow $\cdot$ Turbidite $\cdot$ Ordos Basin $\cdot$ Petrology $\cdot$ Reservoir properties

\section{Introduction}

The formation of deep-water sandstones has attracted considerable attention in both the oil industry and the field of sedimentology (Dalla and Gamberi 2010; Bourget et al. 2010; Talling et al. 2012). In total, 945 major oil and gas fields were discovered around the world from 1859 to

Edited by Jie Hao

Ai-Hua Xi

aihuaxi@163.com

1 School of Geoscience and Technology, Southwest Petroleum University, Chengdu 610500, Sichuan, China

2 PetroChina Research Institute of Petroleum Exploration \& Development-Northwest, Lanzhou 730020, Gansu, China

3 Key Laboratory of Reservoir Description, CNPC, Lanzhou 730020, Gansu, China
2007, of which 341 (34\%) were in passive-continentalmargin deep-water environments (Zou et al. 2009). In addition, large oil and gas reservoirs related to deep-water sandstones have been discovered in numerous continental basins in China (Fu et al. 2013; Yang et al. 2012; Pan et al. 2013). In $2006,3000 \mathrm{~km}^{2}$ of thick deep-water gravity-flow sands were discovered in the Chang $6_{3}$ of the Triassic Yanchang Formation, Huaqing, Ordos Lake Basin. The main types of deep-water gravity-flow deposits are rockslides, slumps, liquefied flows, sandy debris flows, muddy debris flows, and turbidites (Yang et al. 2014; Liu et al. 2015). Of these deposits, sandy-debris-flow and turbiditycurrent sandstones have good reservoir properties and the closest association with oil and gas. The relation between turbidites and sandy debris flows is rather complex and cannot be explained by the turbidite flow model (Shanmugam 1996; Pouderoux et al. 2012; Mulder et al. 1997; Haughton et al. 2009; Sumner et al. 2012; Migeon et al. 
2010; Kane and Pontén 2012). Previous studies mainly focused on the macroscopic properties and models of sandy-debris-flow and turbidity-current sandstones. Macroscopically, the latter possesses the depositional characteristics of section $\mathrm{AB}$ of turbidity-current sandstones. It is difficult to identify them in terms of outcrop study and cores. Consequently, disputes on the understanding of sandy debris flows and turbidite flows have arisen, which have also hindered further exploration (Shanmugam and Moiola 1995; Shanmugam 2013; Li et al. 2015; Stow and Johansson 2000; Talling et al. 2012; Mulder and Alexander 2001). Therefore, it is meaningful to conduct research by comparing the characteristics of these two types of sandstone, especially the micropetrology, formation mechanisms, and differences in reservoir properties.

\section{Geologic setting}

The Ordos Basin is the second-largest petroliferous basin of China, with an area of $25 \times 10^{4} \mathrm{~km}^{2}$. The Upper Triassic Yanchang Formation is the main oil-bearing formation in the basin. The Yanchang Formation is subdivided

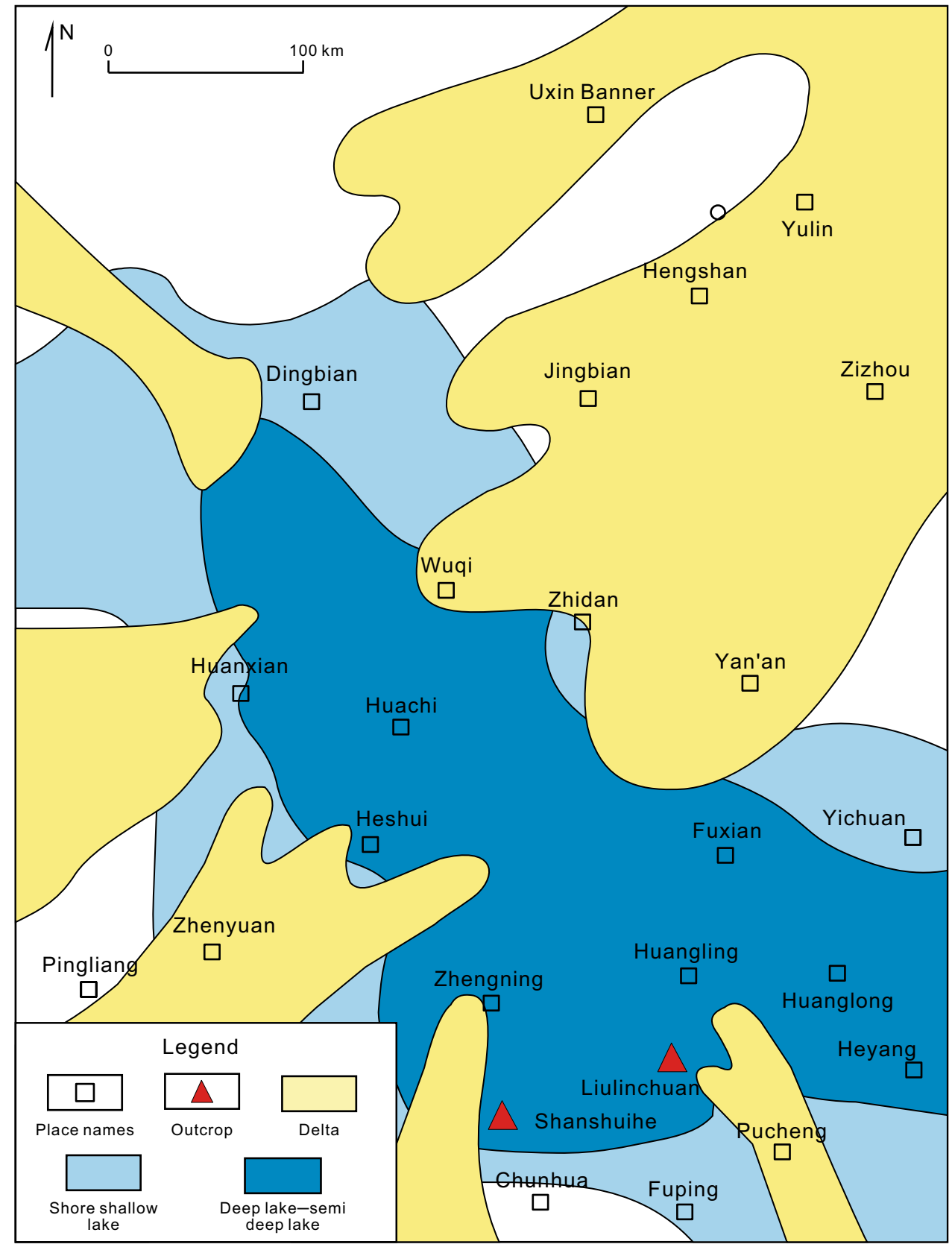

Fig. 1 Lake-delta depositional system in the Ordos Basin during the Yanchang period (according to Li et al. 2016) 
into ten oil-bearing members (Yang 2002; Xu et al. 2016). From top to bottom, the Chang 10 to Chang 8 members represent the early development stages of the basin; the Chang 7 represents the expansion stage; the Chang 6 represents the filling stage of the large-scale delta; the Chang 4 and 5 represent the short small-scale lake expansion, and

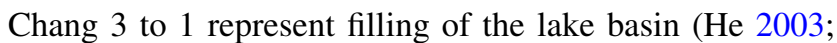
Yu et al. 2001; Lin et al. 2008). A large deltaic depositional system formed in the lake basin during the Chang 7 to Chang $6_{3}$ stage, forming many moderately deep to deep lake deposits along the basin center at Wuqi-FuxianHuangling-Heshui-Huanxian-Dingbian ( $\mathrm{Li}$ et al. 2016; Zou et al. 2012; Fig. 1). Recently, a reservoir of billion- tonne scale was discovered during exploration of deepwater depositional bodies in this area. The main oil-bearing sandstones are sandy-debris-flow sandstones and turbiditycurrent sandstones (Fu et al. 2010). Research on these two types of sandstone, particularly the microscopic petrology, formation mechanism, and reservoir properties, is of significant theoretical and practical use.

The outcrop sections of Shanshuihe in Xunyi County and Liulinchuan in Tongchuan County (Fig. 1) were selected for study. The Chang 7 member of the Shanshuihe section is exposed in northeastern Xunyi County. The lithological succession of this member normally consists of several sets of gray-black oil shale, thick gray-green to
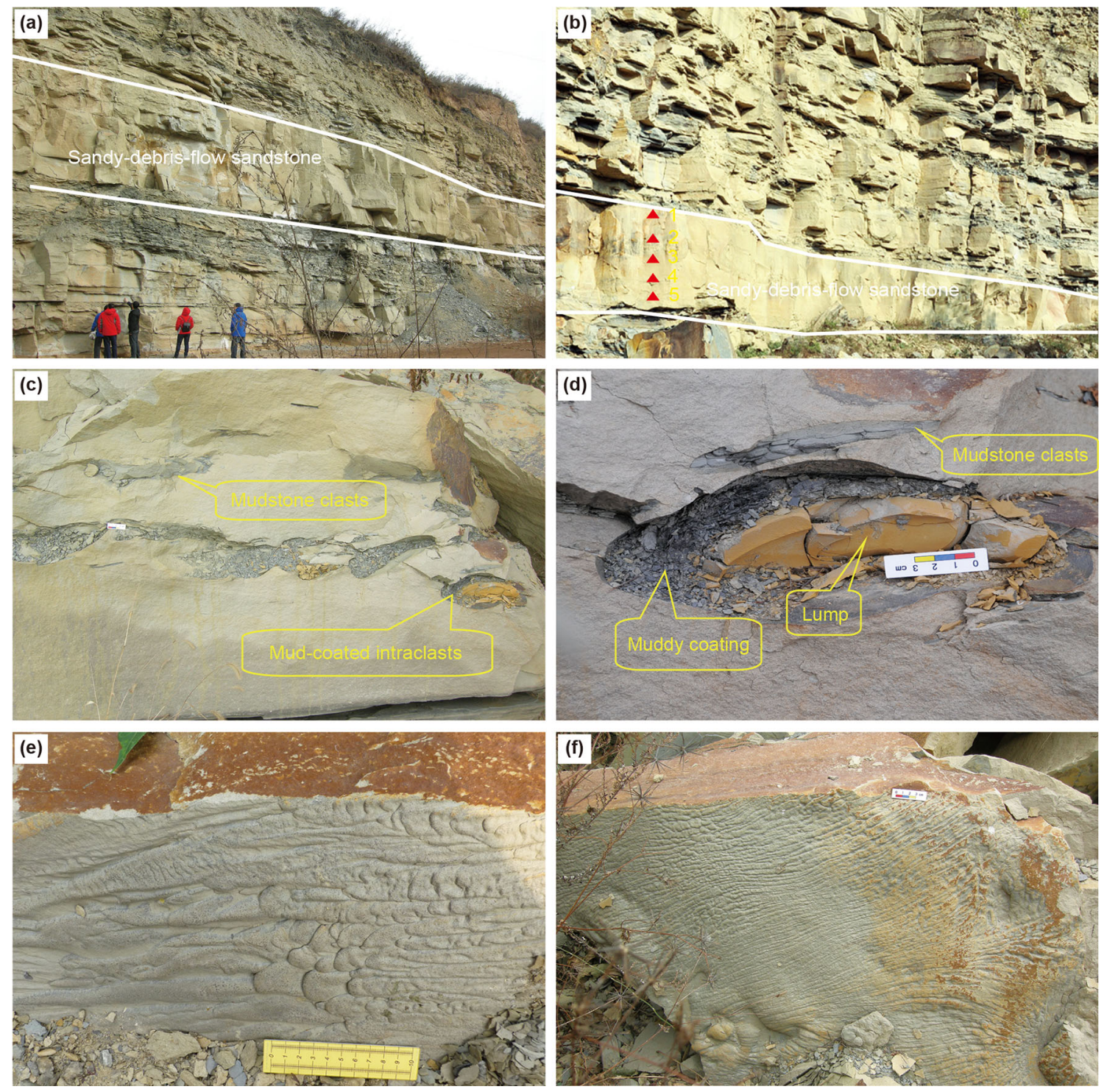

Fig. 2 Outcrop and sedimentary structures. a Panoramic view of the Shanshuihe outcrop; b panoramic view of the Liulinchuan outcrop; c Liulinchuan outcrop, floating mudstone clasts, and mud-coated intraclasts in sandy-debris-flow sandstone; d Liulinchuan outcrop,

mud-coated intraclasts in sandy-debris-flow sandstone; e Shanshuihe outcrop, flute casts in turbidity-flow sandstone; f Liulinchuan outcrop, groove casts in turbidity-flow sandstone 
yellow-green massive fine-grained sandstone, and thinbedded fine-grained sandstone-siltstone (Fig. 2a). The bottom of the Chang 7 member in the Liulinchuan section is composed of a set of yellow-gray massive oil-bearing fine-grained sandstone that thins upward and is interbedded with thin-bedded dark gray shale (Fig. 2b).

Previous studies demonstrated that the thick massive sandstones in the two sections represent semi-deep to deep lake sandy-debris-flow deposition ( $\mathrm{Li}$ et al. 2011a, b). The massive sandstones, which are usually thicker than $0.5 \mathrm{~m}$ and have a maximum thickness of $3 \mathrm{~m}$, are associated with dark gray mudstone (muddy-debris-flow mudstone), thin sandstone, and gray-black laminated shale of semi-deep lake deposition. The base of the sandstones has a sharp contact with the semi-deep lake shale with a relatively flat contact surface, whereas the top of the sandstones is in contact with thin turbidite sandstone (Fig. 2a, b). The sandy-debris-flow sandstones have abundant internal depositional structures. Floating mudstone clasts and mudcoated intraclasts can be observed. The sharp-edged mudstone clasts are elongated and are aligned in their long direction (Fig. 2c, d). The mud-coated intraclasts have a two-layered structure, being composed of a spindle-shaped or oval-shaped block as an inner layer and a muddy or silty mud coating less than $3 \mathrm{~cm}$ thick as an outer layer (Fig. 2c, d). The thin-bedded sandstone is mainly turbidity-current deposits ( $\mathrm{Li}$ et al. 2011a, b). This sandstone is $<0.5 \mathrm{~m}$ thick and is associated with blocky sandstone and semideep lake shale. Depositional structures including normally graded bedding (section A of the Bouma sequence, Fig. $3 \mathrm{~g}$, j), parallel bedding, and sandy laminations, as well as load, flute, and groove casts at the bottom of graded bedding, can be observed (Fig. 2e, f).

\section{Samples and analytical methods}

Two different types of sandstone (sandy debris flow and turbidity-current deposition) were sampled systematically and studied by means of thin sections and grain-size analysis, as well as detailed comparison of microscopic petrological characteristics and reservoir properties. The samples used for thin sections were obtained from the Liulinchuan outcrop. Specifically, five pieces of sandydebris-flow sandstones were collected at equal intervals between the top and bottom of a massive sandstone (Fig. 2b); three pieces of turbidity-current sandstones were also obtained. These samples were selected and cut and then polished on both sides to form 0.03-mm-thick slices. The thin sections were examined using an Axio Scope A1 microscope made by Zeiss. The samples used for grain-size analysis were obtained from the Liulinchuan and Shanshuihe outcrops, and consisted of two pieces of sandy-
Fig. 3 Depositional characteristics and thin-section images of the sandy-debris-flow and turbidity-flow sandstones. a Liulinchuan, bottom of the sandy-debris-flow sandstone, see also label 5 in Fig. 2b, with poor sorting and non-directionally orientated elongated minerals; b Liulinchuan, bottom of the sandy-debris-flow sandstone, see also label 4 in Fig. $2 b$, with a high content and uneven distribution of matrix, pores are developed in the central area; $\mathbf{c}$ Liulinchuan, middle of the sandy-debris-flow sandstone, see also label 3 in Fig. 2b, feldspar dissolution pores and residual intergranular pores; $\mathbf{d ~ L i}$ ulinchuan, middle of the sandy-debris-flow sandstone, see also label 2 in Fig. 2b, intergranular pores; e Liulinchuan, top of the sandy-debrisflow sandstone, see also label 1 in Fig. $2 b$, with a disorganized distribution of detritus and a high content of matrix; f Liulinchuan, turbidity-current sandstone with an integrated Bouma sequence: The $\mathrm{Ta}, \mathrm{Tb}$, and Tc units can be observed; $\mathbf{g}$ Liulinchuan, turbidity-current sandstone, oriented thin section of the Ta section, normally graded bedding can be observed with few pores; $\mathbf{h}$ Liulinchuan, turbiditycurrent sandstone, $\mathrm{Tb}$ section, with slight direction-oriented alignment and extremely low plane porosity ratio; i Liulinchuan, turbiditycurrent sandstone; $\mathbf{j}$ Liulinchuan, turbidity-current sandstone, direction-oriented thin section of Ta, with normally graded bedding, a high matrix content, and no visible pores

debris-flow sandstone and two pieces of turbidity-current sandstone. Both these rock types were sampled from every outcrop. The analysis was carried out by the National Engineering Laboratory of Low Permeability Oil \& Gas Field Exploration and Development following the sieve analysis method and the SY/T5434-2009 testing standard. The samples used for analysis of reservoir properties analysis were from the Liulinchuan and Shanshuihe outcrops. A total of ten pieces of sandy-debris-flow sandstones were obtained; specifically, in each outcrop, five pieces were sampled from massive sandstones in different parts of the section. In addition, 18 pieces of turbidity-current sandstones were obtained, of which six were from the A section, seven from the B section, and five from the $\mathrm{C}$ section. Using a fully automatic overburden-pressure pore and permeability tester and following the SY/T6385-1999 testing standard, the analysis was completed by the CNPC Key Laboratory of Reservoir Description.

In addition, various lithologies, including the floating mudstone clasts within the massive sandy-debris-flow sandstones, the clay coating of the mud-coated intraclasts, the muddy-debris-flow mudstones (dark gray silty mudstone) that are usually associated with the sandy-debrisflow sandstones, and the semi-deep lake laminated shale, were selected for sampling. Sampling was carried out for geochemical analysis to determine the relation between the depositional structure of the mud content of the inner blocky-shaped sandstone and the associated muddy debris flow and laminated shale. Subsequently, the formation mechanism of the rock was studied. The samples used were obtained from the Liulinchuan and Shanshuihe outcrops, and consisted of two pieces of semi-deep lake laminated 

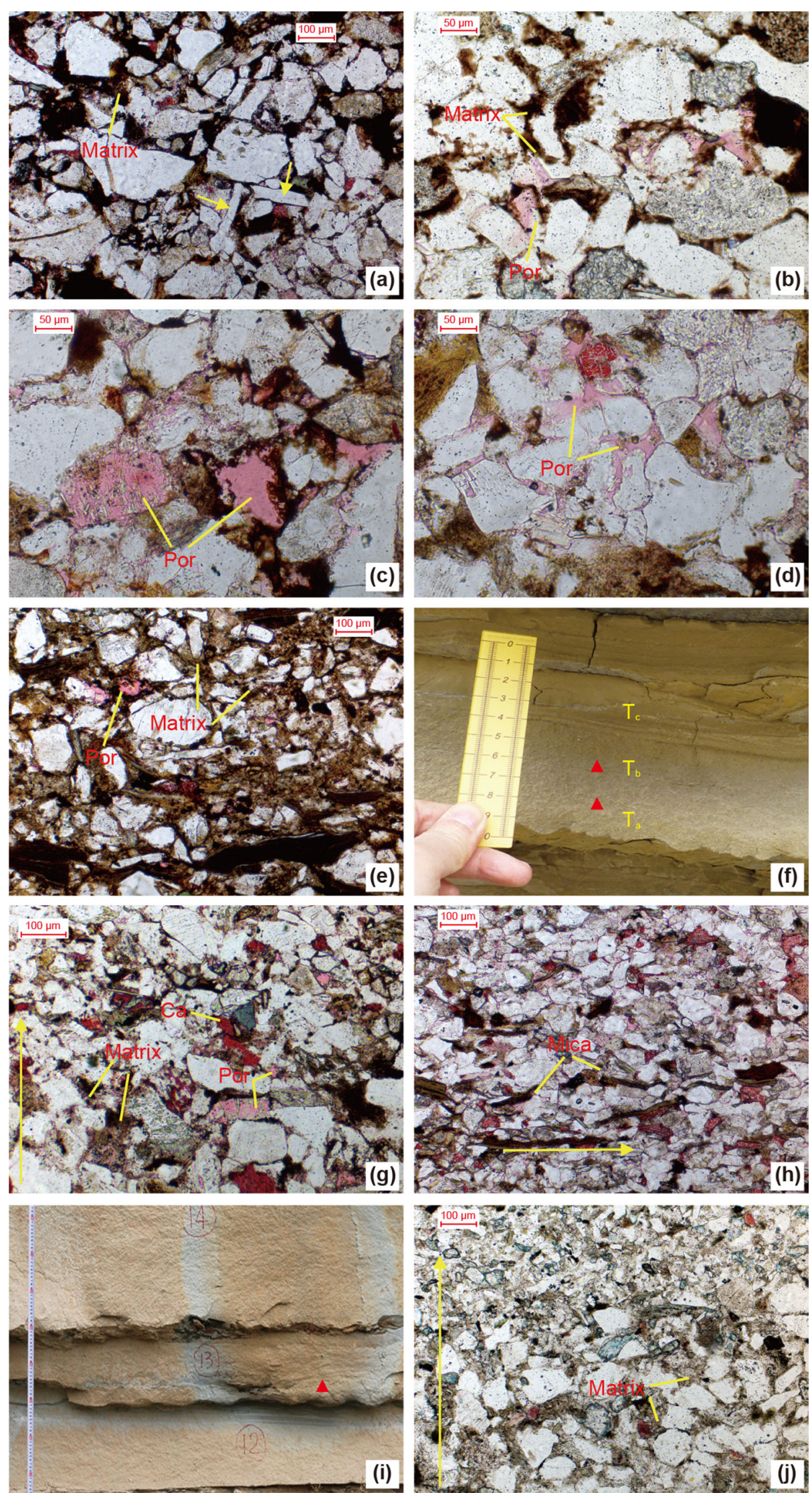
shale, three pieces of muddy-debris-flow mudstones, and six pieces of mudstone clasts and clay coatings from the mud-coated intraclasts. The major elements were determined using a ThermoFisher IRIS Advantage inductively coupled plasma optical emission spectroscope; minor elements were measured using a ThermoFisher VG-X7 inductively coupled plasma mass spectrometer. The geochemical analysis was performed at the State Key Laboratory of Marine Geology (Tongji University). A mixture of $\mathrm{HNO}_{3}$ and $\mathrm{HF}$ was employed to remove silicate and carbonate minerals. In addition, we monitored the stability of the instruments using $1 \mathrm{ppb}$ of $\mathrm{Re}$ and $\mathrm{Rh}$ as internal standards and the GSR-5, GSR-6, and GSD-9 standards for blanks and standardization. The relative standard deviation of the major and minor elements was $1 \%$ and less than $2 \%$, respectively.

\section{Microscopic petrological characteristics}

\subsection{Sandy-debris-flow sandstones}

The sandy-debris-flow sandstones have a total detritus content of $68 \%-75.6 \%$, which is $10 \%-20 \%$ higher than that of the turbidite sandstone (Table 1). The matrix constitutes about $8 \%-15.7 \%$, and the mica content is about 6\%-13.3\%. Together, the matrix and mica make up 19\%$25.3 \%$ of the rock (Table 1). Compared to the turbidite sandstone, the amount of fine-grained matrix and sheetlike mica of mechanical deposition in the sandy-debrisflow sandstones is relatively low (Table 1). Macroscopically, the rock has a homogeneous massive structure. In terms of microscopic structure visible through microscope observation, the rock contains various sizes of grain with poor sorting and a high content of matrix. Also, the elongated minerals have a disorderly distribution with no determined direction (Fig. 3a, e), indicating that re-transportation took place.

\subsection{Turbidity-flow sandstones}

The turbidity-flow sandstones have a detritus content of $53 \%$ and $62.5 \%$, which is lower than that of the sandydebris-flow sandstones. The matrix constitutes about $14 \%-$ $28.3 \%$ of the rock; the mica content is about $12 \%-19 \%$. The matrix and mica together account for $33.8 \%-43.3 \%$ of the rock (Table 1). As a result of the influence of fluid traction, the long axis direction of sheet-like mica and detrital grains are directionally aligned, which is especially obvious in the $T_{b}$ section (Fig. 3h). In an oriented thin section, the Ta section of the turbidite shows grading under the microscope, with the grain size becoming finer from base to top (Fig. 3g, j).

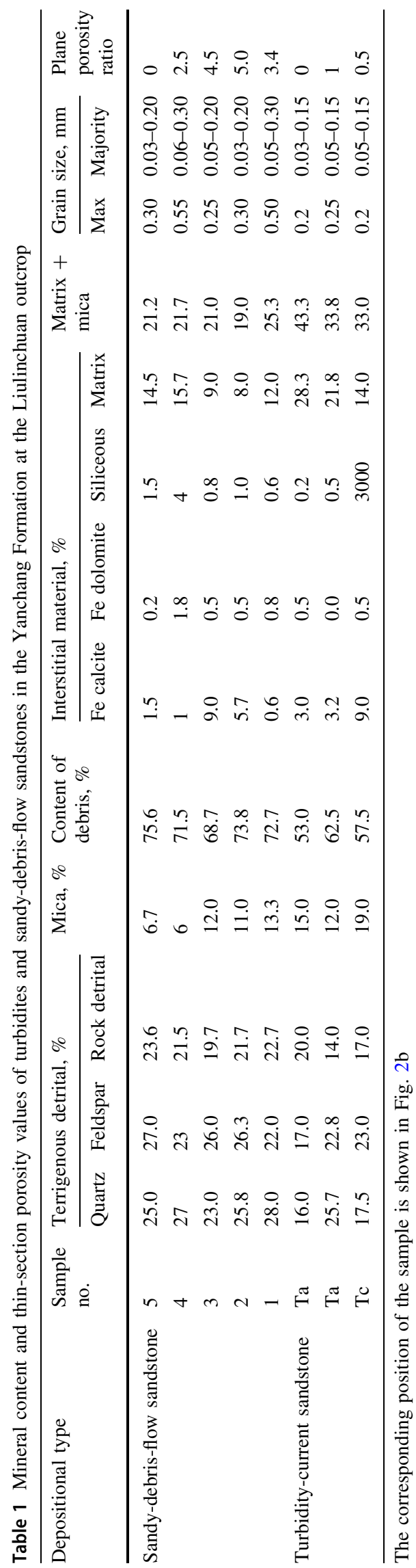




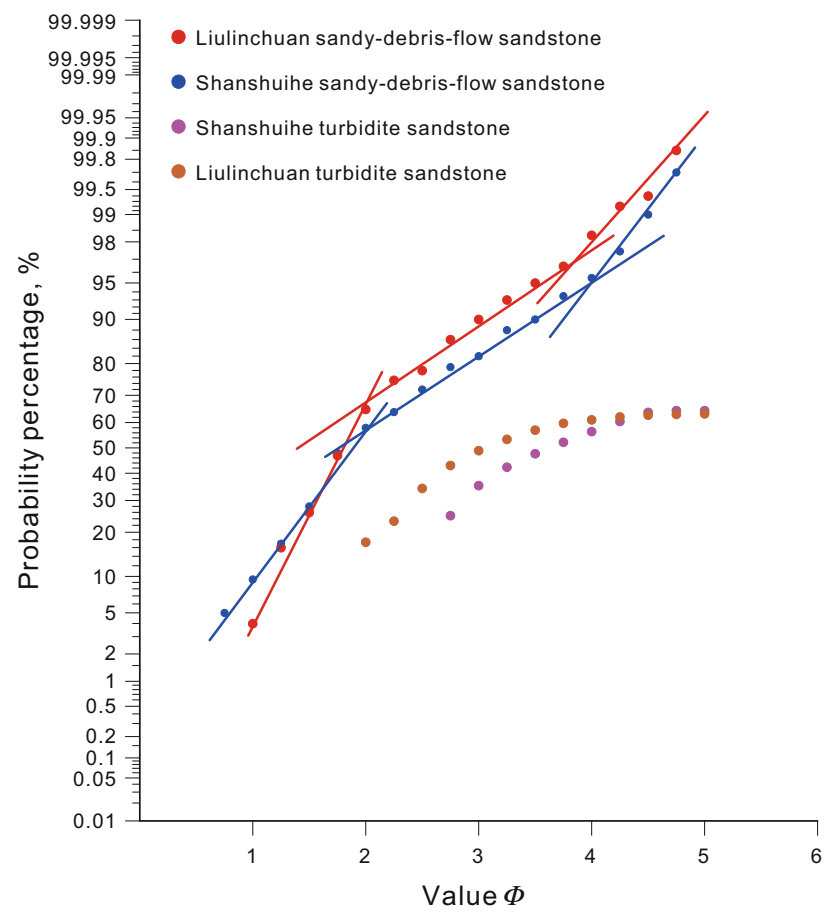

Fig. 4 Cumulative probability curves of grain size for the sandydebris-flow and turbidity-flow sandstones

The differences in petrology between the sandy-debrisflow sandstones and the turbidity-flow sandstones were mainly caused by differences in the transport mechanism. The former is a mass transport deposit and the density of the deposits is high. As the transport distance increases, the concentration of the mass flow gradually diminishes and subsequently transforms to fluid. Finally, fluid transportation takes place. Consequently, the total detrital content of this rock type is low, whereas the contents of mica and matrix are high.

\section{Grain-size characteristics}

\subsection{Sandy-debris-flow sandstones}

The grain-size distribution curve of the sandy-debris-flow sandstones (Fig. 4) has a high slope, with a saltating, a suspended, and a transitional zone (Yuan et al. 2005). The saltating component exhibits good sorting, with a slope higher than $50^{\circ}$, and makes up between $60 \%$ and $70 \%$ of the total grains. The transition zone exhibits medium sorting and represents between $20 \%$ and $25 \%$ of the total. The suspended component constitutes less than $10 \%$ of the total. The $\Phi$ value of the cutoff point between the saltating and the suspended component is 2 , and the $\Phi$ value of the transition zone is about 2-4.25 (Fig. 4). As the sandy debris flow is a type of gravity-flow transformed from a delta-front sandstone, the grain-size re-deposits by secondary transport. The original depositional structures of sandstones were destroyed to some extent (bedding was destroyed and different lithologies became mixed), and the detrital grains were realigned, leading to the mixed grainsize distribution and poor sorting; however, the constitution and grain-size fraction of the detrital grains were not changed. Consequently, the probability distribution of the different grains is similar to those of a delta distributary channel or mouth-bar deposit.

\subsection{Turbidity-current sandstones}

In the grain-size probability curves for the turbidite sandstones, the transition between the saltating and the suspended components is a gradual transition with no obvious turning point, forming a gentle curve that is slightly convex upward (Fig. 4). Overall, the grain size is fine with a broad distribution of $\Phi$ values from 2 to 5. Saltating and rolling components, which would indicate a low slope and poor sorting, are not developed; moreover, the suspended fraction is dominant (Fig. 4).

\section{Comparison of reservoir properties}

\subsection{Sandy-debris-flow sandstones}

In the sandy-debris-flow sandstones, residual interparticle pores are the dominant pore type, with a small number of feldspar solution pores (Fig. 3b-d). Within a single sandstone body, the distribution of pores is strongly heterogeneous. Pores are well developed in the middle part of the sandstone body, where grain sorting is good. From the thinsection analysis, the plane porosity ratio can reach $2.5 \%$ 5\% (Fig. 3b-d; Table 1). The sorting at the top and bottom of the sandstone body is relatively poor. The abundant matrix is evenly distributed within the pores, leading to serious damage to pores. The plane porosity ratio is usually less than $1 \%$ (Fig. 3a, e; Table 1).

From the core testing analysis, the permeability and porosity of the sandy-debris-flow sandstones are relatively high. The porosity is between $6.03 \%$ and $15.1 \%$, with an average value of $12.9 \%$. The permeability is $0.09-1.12 \mathrm{mD}$, with an average value of $0.51 \mathrm{mD}$ (Table 2).

\subsection{Turbidity-current sandstones}

From observations of thin sections, in the turbidity-current sandstones the fine-grained matrix is evenly distributed in the pores, resulting in serious damage to pores. The extremely low plane porosity ratio is usually less than $1 \%$, 
Table 2 Reservoir properties of sandy-debris-flow and turbidity-current sandstones in the Yanchang Formation

\begin{tabular}{|c|c|c|c|c|c|c|}
\hline \multirow[t]{2}{*}{ Depositional type } & \multirow[t]{2}{*}{ Number of samples } & \multicolumn{2}{|l|}{ Porosity, $\%$} & \multicolumn{2}{|c|}{ Permeability, $\times 10^{-3} \mu \mathrm{m}^{2}$} & \multirow[t]{2}{*}{ Sedimentary section } \\
\hline & & Range & Average & Range & Average & \\
\hline Sandy-debris-flow sandstone & 10 & $6.03-15.12$ & 12.89 & $0.09-1.12$ & 0.51 & - \\
\hline \multirow[t]{3}{*}{ Turbidity-current sandstone } & 6 & $5.11-11.12$ & 9.75 & $0.03-0.312$ & 0.152 & Section A \\
\hline & 7 & $4.83-10.99$ & 9.34 & $0.02-0.18$ & 0.102 & Section B \\
\hline & 5 & $4.80-10.1$ & 8.83 & $0.01-0.15$ & 0.058 & Section $\mathrm{C}$ \\
\hline
\end{tabular}

and there are some areas without pores (Fig. 3g, j; Table 1).

The permeability and porosity of the turbidity-current sandstones are relatively low. Normally, porosity is less than $10 \%$ and permeability is no more than $0.15 \mathrm{mD}$. The porosity is relatively better in the A section. The permeability is between 0.03 and $0.312 \mathrm{mD}$, with an average value of $0.152 \mathrm{mD}$. The reservoir properties are relatively inferior in the $\mathrm{B}$ section. The permeability is $0.02-0.18 \mathrm{mD}$, average $0.102 \mathrm{mD}$. The $\mathrm{C}$ section has the worst reservoir properties: The permeability is $0.01-0.15 \mathrm{mD}$, average $0.058 \mathrm{mD}$ (Table 2).

\subsection{The overall reservoir properties of the sandy-debris-flow sandstones are superior to those of the turbidity-current sandstones. There are three reasons to account for this}

Firstly, the detrital content of the sandy-debris-flow sandstone is high: In thin section, the content of detrital grains is usually more than $70 \%$. In the mechanical depositional process, the levels of fine-grained matrix and sheet-like mica are relatively low (Table 1), which is beneficial for the formation of reservoir pores. In contrast, the detrital concentration of the turbidites is low: In thin section, the content of detrital grains is usually less than $65 \%$. In the mechanical depositional process, the levels of fine-grained materials and sheet-like mica are relatively high (Table 1), which is unfavorable for the formation of reservoir pores.

Secondly, the sandy-debris-flow sandstones are mass transport deposits. During the mass transport process, the sandy-debris-flow sandstones would have become entangled in a contiguous mud layer as a result of plastic shearing. Because of this process, the lithologies were mixed to some extent (Fig. 8); however, mixing was not complete. This incomplete mixing is manifested as strong heterogeneity in the sandy-debris-flow reservoirs. In the spaces where the mixing effect was thorough, the pores would have been lost because of infilling by the finegrained muddy component and poor sorting. In spaces where the mixing effect was not thorough, some pores are still preserved: This is especially obvious in the thick, blocky sandstone. Mixing of the lithologies was thorough at the top and bottom of this unit (Fig. 3a, e), but was weak in the middle part. The pores were preserved well with good reservoir properties (Fig. 3b-d). A turbidity current is a type of fluid transport (containing liquid and solid particles supported by the liquid turbulence). The fine-grained matrix infilled the pores evenly, leading to serious damage to pores (Fig. $3 \mathrm{~g}, \mathrm{j}$ ).

Thirdly, a gravity flow is initially of high density. In the late decline stage, the density decreases as deposition progresses. Compared to the sandy debris flow, the transport distance of a turbidity current is relatively further and the deposit is thinner. Consequently, a single layer of the turbidite sandstone is thin, normally less than $0.5 \mathrm{~m}(\mathrm{Li}$ et al. 2011a, b), and relatively fine-grained. From the thinsection analysis, the detrital grain size is between 0.03 and $0.15 \mathrm{~mm}$ (Table 1). A single layer of the sandy-debris-flow sandstones is thick, normally more than $0.5 \mathrm{~m}$ ( $\mathrm{Li}$ et al. 2011a, b), with a detrital grain size between 0.03 and $0.3 \mathrm{~mm}$ (Table 1). In light of this, the reservoir properties of turbidity-current sandstones are inferior to those of sandy-debris-flow sandstones. Considering all the three points listed above, the reservoir properties of sandy-debris-flow sandstones are superior.

A previous study demonstrated that the gravity-flow sandstones of the Chang 6 to Chang 7 members mainly occur in the central part of the lake basin (Fu et al. 2010). Of the gravity-flow sandstones, the sandy-debris-flow sandstones are thicker and the reservoir quality is better. In addition, these sandstones directly cover the source rocks of the Chang 7 member. Therefore, a good source-reservoir assemblage has been formed, which is also a favorable pay zone for oil and gas exploration. 


\section{Formation mechanism of sandstones}

\subsection{Formation mechanism of sandy-debris-flow sandstones}

\subsubsection{Support mechanism}

The floating mudstone clasts and mud-coated intraclasts in the massive-debris-flow sandstones are not related to sand migration attributed to flowing water. If there had been a significant influence of fluid, the mudstone clasts and the muddy coating of the mud-coated intraclasts would have been damaged by the flow of the current. These structures are difficult to preserve. The support of the clasts by the sand indicates that the floating mudstone clasts and mudcoated intraclasts are suspended within the sand-dominated matrix (containing a small amount of water and clay), which was formed during penecontemporaneous sedimentation.

\subsubsection{Depositional environments indicated by mudstone clasts and muddy coatings}

Direct observation and laboratory simulation of the transport and depositional processes of mass flow (subaqueous debris flow) deposits are difficult; accordingly, understanding of their formation mechanism has been affected. The presence of floating mudstone clasts and mud-coated intraclasts in sandstones that originated from a sandy debris flow is a common depositional phenomenon. Study of the origin and formation of these muddy clasts is significant for understanding the formation mechanism of massive sandstone.

1. Analysis of oxidizing and reducing conditions

Uranium $(\mathrm{U})$ is a valence-variable element, with a valence of +4 under reducing conditions. Because of its solubility in water, $\mathrm{U}$ is abundant in sediments; however, it has a valence of +6 , which is easily dissolvable, in oxidizing environments, leading to the loss of $\mathrm{U}$. Thorium (Th) has a valence state of +4 and is immobile; thus, the $\mathrm{Th} / \mathrm{U}$ ratio is often used to determine the redox state of deposits (Deng and Qian 1993; Zhang et al. 2008, 2011). In addition, the autogenous uranium $(\mathrm{U}-\mathrm{Th} / 3)$ content is generally regarded as an important environmental indicator of ancient sediments. Previous studies established the parameter $\delta \mathrm{U}=2 \mathrm{U}_{\text {total }} /\left(\mathrm{U}_{\text {total }}+\mathrm{Th} / 3\right)$ using $\mathrm{U}-\mathrm{Th} / 3$ and total uranium: $\delta \mathrm{U}>1$ implies an anoxic environment and $\delta \mathrm{U}<1$ suggests oxic water (Wignall 1994; Steiner et al. 2001; Wignall and Twitchett 1996; Jones and Manning 1994).

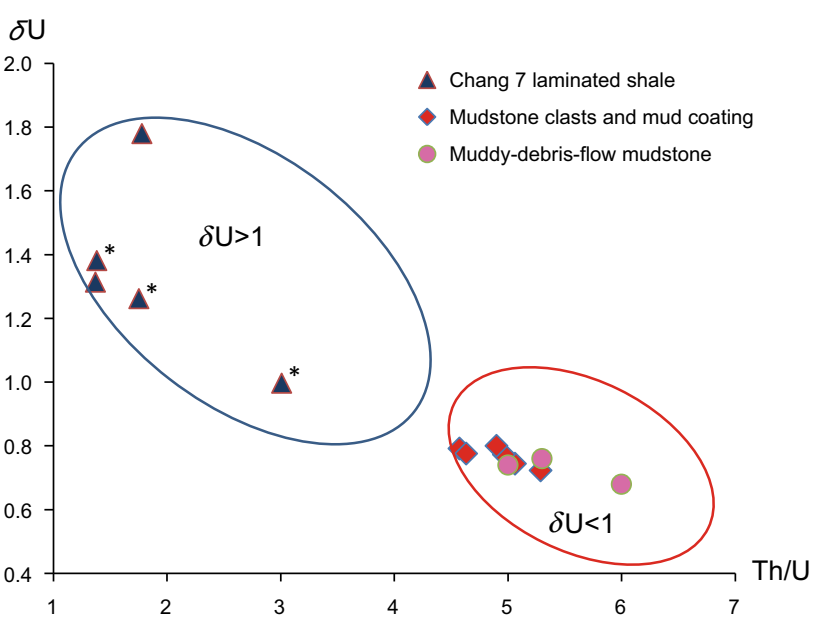

Fig. $5 \delta \mathrm{U}$ and $\mathrm{Th} / \mathrm{U}$ values of the mudstone clasts and mud coating, laminated shale, and muddy-debris-flow mudstone. The data for laminated shale marked * were obtained from the Changqing Oilfield Research Institute (Zhang et al. 2011)

In the sandy-debris-flow sandstones, the mudstone clasts and muddy coating layers are similar to the associated muddy-debris-flow mudstones, in which $\delta \mathrm{U}<1$ and the $\mathrm{Th} / \mathrm{U}$ values are 4.6-5.3. These values indicate $\mathrm{U}$ loss in an oxidizing environment. Conversely, $\delta \mathrm{U}>1$ and the $\mathrm{Th} / \mathrm{U}$ values are 1.4-3.4 in the layered mudstones of the semideep lacustrine facies, in contrast to the mudstone clasts, muddy coating layer, and muddy-debris-flow mudstones (Fig. 5).

\section{Paleosalinity analysis}

The strontium ( $\mathrm{Sr}$ )-to-barium (Ba) ratio is used to estimate paleosalinity. The solubility of $\mathrm{Ba}$ compounds is lower than that of $\mathrm{Sr}$ compounds, and the combination of $\mathrm{Ba}^{2+}$ and $\mathrm{SO}_{4}{ }^{2-}$ in channels precipitates insoluble $\mathrm{BaSO}_{4}$. Therefore, near-shore sediments are enriched in $\mathrm{Ba}$, and $\mathrm{Sr}$ is abundant in deeper-water areas owing to its strong migration ability (Deng and Qian 1993). From previous studies of the $\mathrm{Sr} / \mathrm{Ba}$ ratio of continental basins in China, the $\mathrm{Sr} / \mathrm{Ba}$ ratio is more than 1 in saline lake sediments and less than 1 in freshwater sediments (e.g., 1.0-0.6 in semi-saline water facies and $<0.6$ in brackish-water facies) (Deng and Qian 1993; Wang et al. 1979; Zheng and Liu 1999).

$\mathrm{The} \mathrm{Sr} / \mathrm{Ba}$ values of the muddy coating of intraclasts and the underlying layered mudstones can be used to determine the relative salinity during deposition. The $\mathrm{Sr} / \mathrm{Ba}$ values of mudstone clasts and muddy coatings are less than 0.4, excluding some exceptional samples; the values of muddydebris-flow mudstones are also low. In contrast, the $\mathrm{Sr} / \mathrm{Ba}$ values of layered mudstone are high (Fig. 6). These findings suggest that the mudstone clasts and muddy coatings were formed in low-salinity water, which is similar to the 


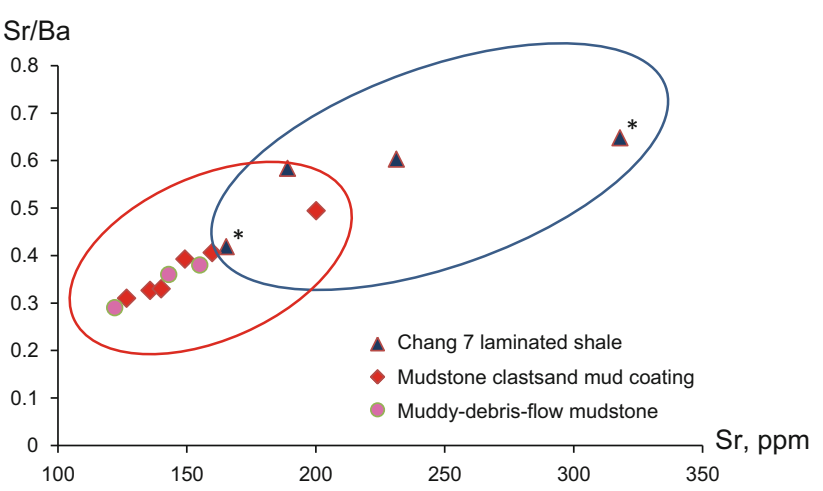

Fig. $6 \mathrm{Sr}$ content and $\mathrm{Sr} / \mathrm{Ba}$ values in mudstone clasts and muddy coatings, laminated shale, and muddy-debris-flow mudstone. The data for laminated shale marked $*$ were obtained from the Changqing Oilfield Research Institute (Zhang et al. 2011)

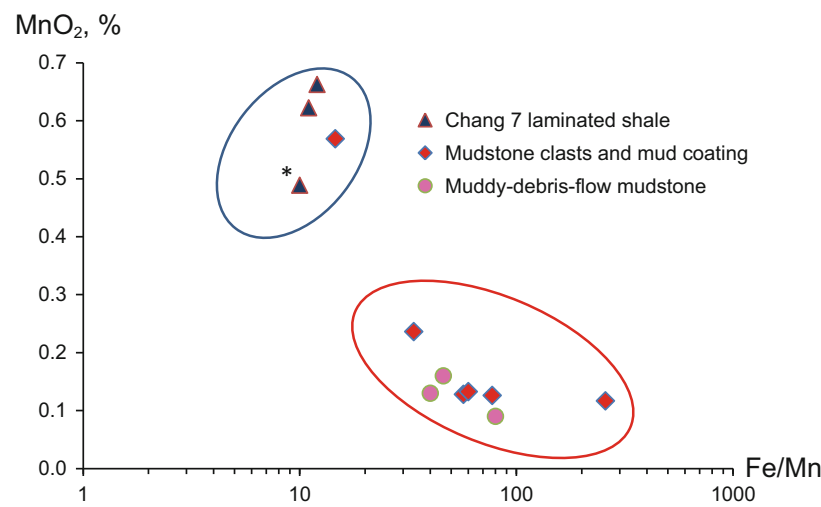

Fig. $7 \mathrm{MnO}_{2}$ content and $\mathrm{Fe} / \mathrm{Mn}$ values in mudstone clasts and muddy coatings, laminated shale, and muddy-debris-flow mudstone. The data for laminated shale marked $*$ were obtained from the Zhongyuan Oilfield Exploration and Development Research Institute (Zhang et al. 2004)

associated muddy-debris-flow mudstones. Conversely, the layered mudstone was developed in high-salinity water.

\section{Paleodepth analysis}

Previous studies demonstrated that iron $(\mathrm{Fe})$ is more concentrated in areas close to land and manganese (Mn) is concentrated in areas relatively far away from shore. The $\mathrm{Fe} / \mathrm{Mn}$ ratio decreases from the shallow to the deep parts of a lake (Deng and Qian 1993; Liu and Zhou 2007; Xiong and Xiao 2011; Zwolsman and Eckb 1999), and the content of $\mathrm{MnO}_{2}$ can be used to discriminate secondary lacustrine subfacies (Zhang et al. 2004). Therefore, the values of Fe/ $\mathrm{Mn}$ and $\mathrm{MnO}_{2}$ are important indices of the offshore distance and paleowater depth of deposits.

In the mudstone clasts and muddy coating layers, the $\mathrm{Fe} /$ $\mathrm{Mn}$ ratio is more than 15 and the $\mathrm{MnO}_{2}$ content is less than $0.3 \%$ (excluding some exceptional samples). In the muddydebris-flow mudstones, the $\mathrm{Fe} / \mathrm{Mn}$ ratio is more than 40 and the $\mathrm{MnO}_{2}$ content is less than $0.2 \%$; in the layered mudstones, the $\mathrm{Fe} / \mathrm{Mn}$ ratio is less than 15 and the $\mathrm{MnO}_{2}$ content is a minimum of $0.5 \%$ (Fig. 7). The high $\mathrm{Fe} / \mathrm{Mn}$ ratio values and low $\mathrm{MnO}_{2}$ contents in the mudstone clasts, muddy coating, and muddy-debris-flow mudstones suggest that they were formed in the same shallow-water environment. In the left upper zone, the genesis of abnormal points of boulder clay and muddy coating are due to the semi-consolidated mudstones that eroded and became mixed in the semi-deep and deep lake in the process of gravity-flow transport and transition. The Fe/ $\mathrm{Mn}$ ratio and $\mathrm{MnO}_{2}$ content are similar to the laminated mudstones of the Chang 7 formation.

\subsubsection{Formation of sandy-debris-flow sandstones}

The muddy coating of the floating mudstone clasts and the mud-coated intraclasts exhibits the geochemical characteristics of near-shore, partially oxidized, and low-salinity sediment. The muddy coating has strong affinities with the associated muddy-debris-flow mudstones and obvious differences from the layered mudstone. The mudstone clasts in the massive sandstone and the muddy coatings of the mud-coated intraclasts were derived from a shallow-water area. In the process of mass transport, as a result of gravity shearing, the shear-resistant sandstones were mixed with a soft muddy layer with weak shear resistance (muddy-debris-flow mudstones) inside the mass flow complex. Thus, oriented sedimentary structures were formed, such as broken-up mudstone clasts and muddy coatings, and massive sandstones with these sedimentary structures were deposited at the foot of an underwater slope or on the flat bottom of the lake. During the formation of these massive sandstones, the characteristics of mass transport were retained. Material exchange and mixing within the soft sandy and muddy sediments occurred because of shear stress (Fig. 8).

\subsection{Formation of turbidity-current sandstones}

A turbidite is the result of fluid transport, and the depositional structures and components of turbidity-current sandstones are not as much as those of sandy-debris-flow sandstones. Mud samples such as floating mudstone clasts and muddy coatings on the mud-coated intraclasts, which are abundant in the sandy-debris-flow sandstones, are not present in the turbidity-current sandstones. It is difficult to conduct quantitative analysis by means of elemental geochemical methods.

During microscope study of the integrated Bouma sequence of a turbidite in outcrop, normal grading was observed in the A section (Fig. 3g, j). This finding proves that during turbidite deposition, owing to the continuous decrease in energy and flow velocity, suspended coarse and 


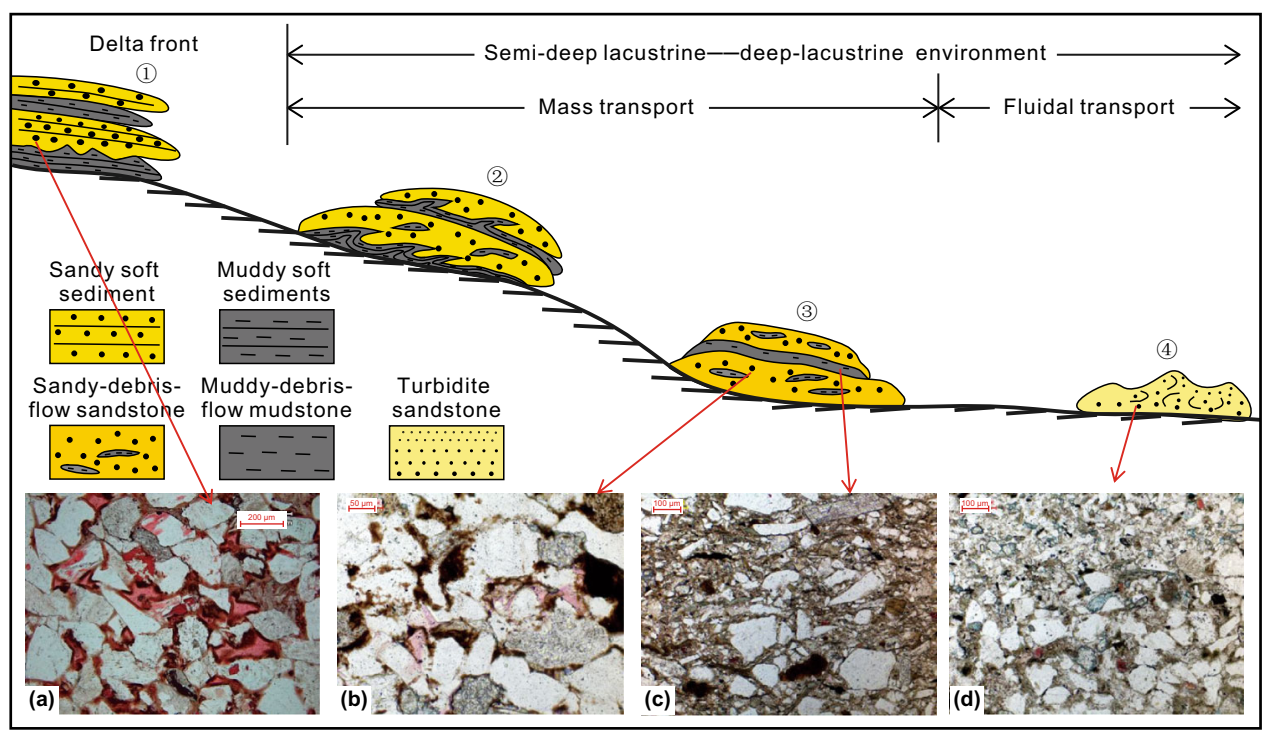

Fig. 8 Transport and deposition diagram of deep-water sandstone in the Yanchang Formation (modified from Li et al. 2016; Shanmugam 2014). (1) The stage of interbedded delta-front sandstone and mudstone; (2) the stage forming mass flow complex; (3) the

fine grains settled according to their respective velocities, indicating turbulent current support of sediment. Directional alignment of sheet-like mica and long elongated minerals can be observed in the B and C sections (Fig. 3h). After deposition of section A, sedimentation of sections B and $\mathrm{C}$ occurred during the transformation from a turbidity current to a traction current owing to the attenuation of energy.

\section{Conclusions}

1. The sandy-debris-flow sandstones contain a large number of detrital particles and small amounts of mica particles and matrix, suggesting mass flow transport. In the turbidity-current sandstones, the content of detrital particles is lower and both mica sheets and matrix are abundant. Normal grading is present, suggesting turbulent-flow transport.

2. In the sandy-debris-flow sandstones, the floating mudstone clasts, the muddy coatings on the mudcoated intraclasts, and the associated muddy-debrisflow mudstones exhibit similar geochemical characteristics that are indicative of shallow water. These sediments originated from a shallow-water area. The presence of sandy and muddy soft depositional layers indicates that material transfer and mixing took place during mass transport. Yet, these sediments still preserved a reservoir space with good properties, containing small numbers of residual interparticles and feldspar solution pores. The turbidity-current depositional stage of the mass flow complex; (4) the depositional stage of turbidite flow. Picture $a$ comes from exploration well Ning X $\mathrm{X}$, and the other pictures of $b, c, d$ are from the Liulinchuan outcrop

sandstones are densely filled with mica sheets and fine-grained matrix, leading to serious damage to the pores and poor reservoir properties.

3. In the middle part of the lacustrine basin, large-scale sandy-debris-flow sandstones directly cover the source rocks of the Chang 7 member. In this way, a good source-reservoir assemblage has been formed, which is also a favorable pay zone for oil and gas exploration.

Acknowledgements This study was funded by the Natural Science Foundation of China (41772099) and the National Science and Technology Major Project (2017ZX05001-003). We would like to thank senior engineers Yuan Xiaoqi and He Jing for their participations in the fieldwork and part of study.

Open Access This article is distributed under the terms of the Creative Commons Attribution 4.0 International License (http://crea tivecommons.org/licenses/by/4.0/), which permits unrestricted use, distribution, and reproduction in any medium, provided you give appropriate credit to the original author(s) and the source, provide a link to the Creative Commons license, and indicate if changes were made.

\section{References}

Bourget J, Zaragosi S, Mulder T, et al. Hyperpycnal-fed turbidite lobe architecture and recent sedimentary processes: a case study from the Al Batha turbidite system, Oman margin. Sediment Geol. 2010;229(3):144-59. https://doi.org/10.1016/j.sedgeo.2009.03. 009.

Dalla VG, Gamberi F. Erosional sculpting of the Caprera confined deep-sea fan as a result of distal basin-spilling processes (eastern Sardinian margin, Tyrrhenian Sea). Mar Geol. 
2010;268(1-4):55-66. https://doi.org/10.1016/j.margeo.2009.10. 012 .

Deng HW, Qian K. Sedimentary Geochemistry and Environment Analysis. Lanzhou: Gansu Science and Technology Press. 1993 (in Chinese).

Fu JH, Deng XQ, Zhang XL, et al. Relationship between deepwater sandstone and tight oil of the Triassic Yanchang Formation in Ordos Basin. J Palaeogeogr. 2013;15(5):624-34. https://doi.org/ 10.7605/gdlxb.2013.05.050 (in Chinese).

Fu ST, Deng XQ, Pang JL. Characteristics and mechanism of thick sandbody of Yanchang Formation at the centre of Ordos Basin. Acta Sediment Sin. 2010;28(6):1081-9 (in Chinese).

Haughton P, Davis C, McCaffrey W, et al. Hybrid sediment gravity flow deposits: classification, origin and significance. Mar Pet Geol. 2009;26(10):1900-18. https://doi.org/10.1016/j.marpet geo.2009.02.012.

He ZX. Evolution and oil-gas in the Ordos basin. Beijing: Petroleum Industry Press. 2003 (in Chinese)

Jones B, Manning DAC. Comparison of geochemical indices used for the interpretation of palaeoredox conditions in ancient mudstones. Chem Geol. 1994;111(1-4):111-29. https://doi.org/10. 1016/0009-2541(94)90085-X.

Kane IA, Pontén ASM. Submarine transitional flow deposits in the Paleogene Gulf of Mexico. Geology. 2012;40(12):1119-22. https://doi.org/10.1130/G33410.1.

Liu F, Zhu XM, Li Y, et al. Sedimentary characteristics and facies model of gravity flow deposits of Late Triassic Yanchang Formation in southwestern Ordos Basin, NW China. Pet Explor Dev. 2015;42(5):577-88. https://doi.org/10.11698/PED.2015.05. 04 (in Chinese).

Li XB, Wang J, Liao JB, et al. The mechanism of transport process of deep-water sedimentation in lacustrine basin: a case study of deep-water sandstone in the Yanchang Formation, Ordos Basin. Nat Gas Geosci. 2015;26(4):625-33. https://doi.org/10.11764/j. issn.1672-1926.2015.04.0625 (in Chinese).

Lin HB, Hou MC, Chen HD, et al. Characteristics and evolution of the sedimentary system of Upper Triassic Yanchang Formation in Ordos Basin, China. J Chengdu Univ Technol Sci Technol Edit. 2008;35(6):674-80 (in Chinese).

Li XB, Yang ZL, Wang J, et al. Mud-coated intraclasts: a criterion for recognizing sandy mass transport deposits-Deep-lacustrine massive sandstone of the Upper Triassic Yanchang Formation, Ordos Basin, Central China. J Asian Earth Sci. 2016;129:98-116. https://doi.org/10.1016/j.jseaes.2016.06.007.

$\mathrm{Li} \mathrm{XB}, \mathrm{Fu} \mathrm{JH}, \mathrm{Chen} \mathrm{QL}$, et al. The concept of sandy debris flow and its application in the Yanchang Formation deep-water sedimentation of Ordos Basin. Adv Earth Sci. 2011a;26(3):286-94 (in Chinese)

Li XB, Chen QL, Liu HQ, et al. Features of sandy debris flows of the Yanchang Formation in the Ordos Basin and its oil and gas exploration significance. Acta Geol Sin. 2011b;85(5):1187-202 (in Chinese).

Liu G, Zhou DS. Application of microelements analysis in identifying sedimentary environment taking Qianjiang Formation in the Jianghan Basin as an example. Pet Geol Exp. 2007;29(3):307-11 (in Chinese).

Mulder T, Savoye B, Syvitski JPM. Numerical modelling of a midsized gravity flow: the 1979 Nice turbidity current (dynamics, processes, sediment budget and seafloor impact). Sedimentology. 1997;44(2):305-26. https://doi.org/10.1111/j.1365-3091.1997. tb01526.x

Migeon S, Ducassou E, Gonidec YL, et al. Lobe construction and sand/mud segregation by turbidity currents and debris flows on the western Nile deep-sea fan (Eastern Mediterranean). Sediment Geol. 2010;229(3):124-43. https://doi.org/10.1016/j.sedgeo. 2010.02.011.
Mulder T, Alexander J. The physical character of subaqueous sedimentary density flows and their deposits. Sedimentology. 2001;48(2):269-99. https://doi.org/10.1046/j.1365-3091.2001. 00360.x.

Pan SX, Zheng RC, Wei PS, et al. Deposition characteristics, recognition mark and form mechanism of mass transport deposits in terrestrial lake basin. Lithol Reserv. 2013;25(2):9-18 (in Chinese).

Pouderoux H, Proust J, Lamarche G, et al. Postglacial (after $18 \mathrm{ka}$ ) deep-sea sedimentation along the Hikurangi subduction margin (New Zealand): characterisation, timing and origin of turbidites. Mar Geol. 2012;295-298:51-76. https://doi.org/10.1016/j.mar geo.2011.11.002.

Shanmugam G, Moiola RJ. Reinterpretation of depositional processes in a classic flysch sequence (Pennsylvanian Jackfork Group), Ouachita Mountains, Arkansas and Oklahoma. AAPG Bull. 1995;79(5):672-95.

Shanmugam G. High-density turbidity currents: are they sandy debris flows? J Sediment Res. 1996;66(1):2-10. https://doi.org/10. 1306/D426828E-2B26-11D7-8648000102C1865D.

Shanmugam G. New perspectives on deep-water sandstones: implications. Pet Explor Dev. 2013;40(3):316-32.

Shanmugam G. Modern internal waves and internal tides along oceanic pycnoclines: challenges and implications for ancient deep-marine baroclinic sands: reply. AAPG Bull. 2014;98(4):858-79. https://doi.org/10.1306/09111313115.

Stow DAV, Johansson M. Deep-water massive sands: nature, origin and hydrocarbon implications. Mar Pet Geol. 2000;17(2):145-74. https://doi.org/10.1016/S02648172(99)00051-3.

Steiner M, Wallis E, Erdtmann B, et al. Submarine hydrothermal exhalative ore layers in black shales from South China and associated fossils-insights into a Lower Cambrian facies and bio-evolution. Palaeogeogr Palaeoclimatol Palaeoecol. 2001;169(3):165-91.

Sumner EJ, Talling PJ, Amy LA, et al. Facies architecture of individual basin-plain turbidites: comparison with existing models and implications for flow processes. Sedimentology. 2012;59(6):1850-87. https://doi.org/10.1111/j.1365-3091.2012. 01329.x.

Talling PJ, Masson DG, Sumner EJ, et al. Subaqueous sediment density flows: depositional processes and deposit types. Sedimentology. 2012;59(7):1937-2003. https://doi.org/10.1111/j. 1365-3091.2012.01353.x.

Wignall PB. Black shales. Oxford: Clarendon press. 1994.

Wignall PB, Twitchett RJ. Oceanic anoxia and the end Permian mass extinction. Science. 1996;272(5265):1155-8. https://doi.org/10. 1126/science. 272.5265.1155.

Wang YY, Guo WY, Zhang GD. Application of some geochemical indicators in determining of sedimentary environment of the Funing Group (Paleogene), Jin-Hu Depression, Kiangsu Province. J Tongji Univ. 1979;7(2):51-60 (in Chinese).

Xu QH, Shi WZ, Xie XY, et al. Deep-lacustrine sandy debrites and turbidites in the lower Triassic Yanchang Formation, southeast Ordos Basin, central China: facies distribution and reservoir quality. Mar Pet Geol. 2016;77:1095-107. https://doi.org/10. 1016/j.marpetgeo.2016.08.011.

Xiong XH, Xiao JF. Geochemical indicators of sedimentary environments-a summar. Earth and Environ. 2011;39(3):405-9 (in Chinese).

Yang H, Fu JH, He HQ, et al. Formation and distribution of large lowpermeability lithologic oil regions in Huaqing, Ordos Basin. Pet Explor Dev. 2012;39(6):641-8 (in Chinese).

Yang RC, He ZL, Qiu GQ, et al. Late Triassic gravity flow depositional systems in the southern Ordos Basin. Pet Explor 
Dev. 2014;41(6):661-70. https://doi.org/10.11698/PED.2014.06. 03 (in Chinese).

Yang JJ. Structural evolution and petroleum distribution rules in the Ordos Basin. Beijing: Petroleum Industry Press. 2002 (in Chinese).

Yu J, Han YL, Lin SJ. Geological characteristics and reservoir types of the Triassic Yanchang Formation in the Ordos Basin. China Pet Explor. 2001;6(4):13-9 (in Chinese).

Yuan WF, Chen SY, Zeng C, et al. Probability cumulative grain size curves in terrigenous of the Tertiary in west Qaidam Basin. J Univ Pet China Edit Nat Sci. 2005;29(5):12-8 (in Chinese).

Zou CN, Zhao ZZ, Yang H, et al. Genetic mechanism and distribution of sandy debris flows in terrestrial lacustrine basin. Acta Sediment Sin. 2009;27(6):1065-75. https://doi.org/10.14027/j. cnki.cjxb.2009.06.022 (in Chinese).

Zou CN, Wang L, Li Y, et al. Deep-lacustrine transformation of sandy debrites into turbidites, Upper Triassic, Central China. Sediment Geol. 2012;265(266):143-55. https://doi.org/10.1016/j.sedgeo. 2012.04.004 (in Chinese).
Zhang WZ, Yang H, Yang YH, et al. Petrology and element geochemistry and development environment of Yanchang Formation Chang-7 high quality source rocks in Ordos Basin. Geochimica. 2008;37(1):59-64 (in Chinese).

Zhang CL, Gao AL, Liu Z, et al. Study of character on sedimentary water and palaeoclimate for Chang7 oil layer in Ordos Basin. Nat Gas Geosci. 2011;22(4):582-6 (in Chinese).

Zheng RC, Liu MQ. Study on palaeosalinity of Chang-6 oil reservoir set in Ordos Basin. Oil Gas Geol. 1999;20(1):20-5 (in Chinese).

Zwolsman JJG, Eckb GTMV. Geochemistry of major elements and trace metals in suspended matter of the Scheldt estuary, southwest Netherlands. Mar Chem. 1999;66(1-2):91-111. https://doi.org/10.1016/S0304-4203(99)00026-2.

Zhang XJ, Fan YF, Zhang JJ, et al. Microlement and geologic significance of Yanchang Formation in Fuxian area, Ordos Basin. Xinjiang Pet Geol. 2004;25(5):483-5 (in Chinese). 